\title{
THE DECLINE OF INTERNATIONAL LAW AS A NORMATIVE IDEAL
}

\author{
Shirley V Scott*
}

International law was integral to the rise in power of the United States and has been central to the operation of world politics during the period in which the United States has been the dominant state. This article draws on the theory of International Law as Ideology to explain the manner in which the ideal of international law as politically neutral has served as a rhetorical fulcrum. The theory also offers a framework within which to perceive and assess the significance of an apparent sidelining of the ideal in global politics, including, notably, by the United States. While reduced use of the ideology of international law and introduction of the term "rules-based international order" or "rules-based order" might be the best strategic option at a time of declining power, the theory of International Law as Ideology illuminates the manner in which these developments may at the same time be unwittingly contributing to that decline.

\section{INTRODUCTION}

The end of World War One represented the beginning of a new era in the history of international law. Grewe refers to a change from the classical law of nations to modern international law. ${ }^{1}$ Modern international law has constituted not only a system of rules, principles, and concepts at global and regional levels, but a normative ideal. The United States has been closely associated with the ideal and was a great promoter of the expansion of international law particularly in the decades after World War Two. There are indications that the ideal is now in decline. There appears to be a dual process underway: the decline is happening both as a consequence of the reduction in the relative power of the United States, but more curiously, the United States and close allies would seem to be actively contributing to the trend. The first half of this article will set out the theoretical basis for the

* Professor and Head of the School of Humanities and Social Sciences, UNSW Canberra. The author would like to thank Dr Tamsin Paige for her valuable research assistance.

1 Wilhelm G Grewe The Epochs of International Law (Michael Byers (translator), Berlin, de Gruyter, 2000) at 575 . 
proposition, drawing on previous scholarship theorising international law as an ideology. ${ }^{2}$ The second half briefly explores two scenarios in which the United States and allies would seem to be choosing options that hasten the decline of international law as a political ideal. The article concludes by seeking to begin to make sense of why they may be choosing this path.

\section{THE UNITED STATES ERA IN INTERNATIONAL LAW}

The United States has played a central role in shaping the contemporary international legal order; despite the United States never joining the League of Nations this was already true of the post-World War One settlement, inclusive of Wilson's Fourteen Points; it became much more pronounced after World War Two. Considerable preparatory work for the United Nations (UN) Charter was undertaken in the United States Department of State. The United States has been one of the most frequent to states to appear before the International Court of Justice and to participate in the Dispute Resolution process of the World Trade Organization. ${ }^{3}$ This is not to say that other countries did not contribute extensively to the development of international law during the 20th century, but to emphasise the primacy of United States leadership.

Grewe divided the history of international law into a series of epochs, each of which was dominated by the great power of that age: Spain from 1494-1648, France from 1648-1815, and Britain from 1815-1919. ${ }^{4}$ Although Grewe himself does not refer to the post-1919 period as the United States era, he defined the dominant power in the system as the one against whose ideas regarding the system all others debate, and on that basis it is possible to conceive of the epoch following 1919 as having been the United States' epoch in international law. ${ }^{5}$ Consider in the academy, for example, the status of the American Journal of International Law and the importance to international law of the annual meetings of the American Society of International Law, which for decades have brought together international lawyers from around the world.

As a system, international law during the United States era has had certain characteristics, which have to a considerable degree reflected aspects of the United States' legal and political system. ${ }^{6}$ Perhaps most fundamentally, there has been a quantitative and qualitative expansion of international

2 The theory was first articulated in Shirley V Scott "International Law as Ideology: Theorising the Relationship between International Law and International Politics" (1994) 5 EJIL 313 and has been developed in a substantial body of literature since.

3 This paragraph draws on Shirley V Scott International Law, US Power: The United States' Quest for Legal Security (Cambridge University Press, Cambridge, 2012).

4 Grewe, above $\mathrm{n} 1$.

5 At 24 .

6 This section draws on Shirley V Scott "Looking Back to Anticipate the Future: International Law in The Era of the United States" in Rowena McGuire, Bridget Lewis and Charles Sampford (eds) Shifting Global Powers and International Law: Challenges and Opportunities (Routledge, Oxon, 2013) 12. 
law, which can be seen as reflecting its domestic polity in which the law is so often a modus operandi; more than 50 per cent of United States presidents and 75 per cent of secretaries of state have been lawyers. ${ }^{7}$ This expansion has led to inroads into the rights of sovereign states - consider, for example, the prohibition on first use of force and the growth of international human rights law, which protects individuals against their own governments. Non-state actors have been important to the creation, implementation and effectiveness of international law although generally without formal responsibility for either, somewhat analogously to the role of civil society within the United States.

During the United States era, treaty law became the most important source of international law and the multilateral treaty became ubiquitous. The United States polity and society is known for being litigious; during the United States era in international law, states have been held increasingly accountable for their actions in respect of international law, including before the growing number of international courts, tribunals and quasi-judicial mechanisms. This rise of positivist international law and litigation fostered the growth of the legal profession. And in diplomacy, international law became a universal, secular medium for bargaining in which sovereignty served as the criterion for participation.

Importantly, within that bargaining and public diplomacy infused with references to international law, international law was widely portrayed as positive and was rhetorically associated with human rights and justice. Principles at a domestic level, such as those of the separation of powers and the rule of law, correspond with the ideal of international law as an objective, apolitical path to a better world. This reflects a great respect for the law within United States society. Law is often referred to rhetorically as if it were a standard higher than, or distinct from, politics despite the fact that most people would be able to see, for example, that politics enters the creation of law by Congress, that different judges might find differently, and that the choice of judge to be appointed to the Supreme Court is a political act.

The ideal of international law as distinct from power politics and alliance systems, was promoted particularly strongly by the United States in the 1930 s and over ensuing decades. ${ }^{8}$ International law has often been portrayed in diplomatic interactions as a normative standard against which behaviour can be assessed. Rhetoric by United States leaders has frequently contrasted international law with power politics and emphasised the common benefits of an international rule of law, arguably the most important of which is peace. President Obama declared: ${ }^{9}$

7 Scott, above $\mathrm{n} 3$, at 10

8 Scott, above n 3.

9 Barack Obama, President of the United States "Obama's Nobel Remarks" (speech at the Nobel Peace Prize ceremony, Oslo, 10 December 2009). 
Those who claim to respect international law cannot avert their eyes when those laws are flouted. Those who care for their own security cannot ignore the danger of an arms race in the Middle East or East Asia.

Those who seek peace cannot stand idly by as nations arm themselves for nuclear war.

Indeed, the notion that international law is an avenue to world peace was at the heart of the international law project of the 19th and 20th centuries. ${ }^{10}$ Growing out of the 19th century peace movement, the ideal was that international disputes be resolved via third party adjudication; in order for such a system to operate, international law needed to be codified. And the great experiment of the 20th century was to forbid states to initiate wars to pursue their political objectives. ${ }^{11}$

\section{INTERNATIONAL LAW AS AN IDEOLOGY}

The theorisation of international law as ideology posits that the ideal of international law has functioned as the central organising set of principles or ideology in the United States-led international order. This is powerful analytically because it means that we can track challenges to the international order via challenges to the ideal and can track shifting usage of the ideal as a harbinger of change in the international distribution of power.

According to a neutral conceptualisation of ideology there is one principle or small set of interrelated principles integral to every socio-political structure. The two are interrelated in the sense that there cannot be change in one without change in the other. Change in the ideology reflects a change in the power structure in which it is embedded; change in the power structure is reflected in a change in the ideology: ${ }^{12}$

The ideology must remain an implicit assumption in debate within that political order ... If the ideology ceases to be upheld, that set of interrelated power relationships will come to an end.

Teased apart, the ideal of international law can be divided into the following principles: ${ }^{13}$

- The principle of political neutrality: the image of international law as distinct from politics or as politically neutral in the sense that it treats all states equally.

10 Shirley V Scott "Inserting Visions of Justice into a Contemporary History of International Law" (2014) 4 Asian JIL 41. On the 19th century project see also Martti Koskenniemi The Gentle Civilizer of Nations. The Rise and Fall of International Law 1870-1960 (Cambridge University Press, Cambridge, 2001).

11 See, inter alia, Oona A Hathaway and Scott J Shapiro The Internationalists and their Plan to Outlaw War (Allan Lane, London, 2017).

12 Scott, above n 2, at 318-319.

13 See Shirley V Scott and Radhika Withana "The Relevance of International Law for Foreign Policy Decisionmaking when National Security is at Stake: Lessons from the Cuban Missile Crisis" (2004) 3 Chinese JIL 163 at $180-181$. 
- The principle of peace through law: it is possible to apply international law objectively so as to settle a dispute between states.

- The principle of compulsory compliance: it is compulsory for a state to comply with its international law obligations.

- The principle of a legal/illegal dichotomy: it is possible to distinguish objectively between legal and illegal action.

- The principle of law preceding policy: international law is timeless, at least in the sense that it pre-dates policy. Ideally, law will dictate an appropriate policy choice.

- The principle of comprehensive coverage: international law can deal with any issue that arises between states.

The principles are interrelated in that, for example, the overarching goal of world peace via international law is achievable because, according to the ideal, international law is politically neutral; the law exists ahead of and guides policy, and treats all states equally.

\section{THE ROLE OF THE IDEOLOGY OF INTERNATIONAL LAW WITHIN THE INTERNATIONAL ORDER}

The ideology can be understood as a fulcrum that has served a role in mediating political positions within the international order. Demonstrating acceptance of the shared idea by members of the political order confirms membership of each individual to the group and at the same time reinforces the ideology. ${ }^{14}$ It is a political obligation of all states in the international order to uphold the ideology - that is, to engage in rhetoric premised on the ideology being true. ${ }^{15}$ Rhetoric about international law in public diplomacy and diplomatic interactions has often portrayed international law as an apolitical benchmark and a binary normative standard against which to measure the appropriateness of action.

Powerful states can draw on the ideology of international law to influence the behaviour of other states. The steps to successful use of the ideology on the part of the United States have been, at least as understood heuristically: to create a shared ideal and desire or obligation on the part of others to uphold that ideal; to ensure an integrated system of regimes underpinned by the ideal that are broadly in United States' interests; and then, as necessary to draw on the shared responsibility to uphold the ideal to impact the behaviour of others so that they need to act as the United States would want them to in order to justify their actions in terms that uphold the ideal. The ideology as used by dominant players in the system serves to disguise the power relationship and presents a source of power as one

14 Scott, above n 2, at 318 .

15 Shirley V Scott "Identifying the Source and Nature of a State's Political Obligation Towards International Law" (2005) 1 JILIR 49. 
of prestige; it presents all members of the political structure as equally placed in relation to the subject of the ideology. ${ }^{16}$

Because the ideology is so valuable to the most powerful state, others within the international order have also been able to use it as leverage during diplomatic manoeuvring. The less powerful could lean on the powerful to realise the vision of international law as politically neutral both in the creation of new law and in diplomatic tussles. If in a dispute, each state can seek to point to discrepancies between the ideology and the behaviour of the opposing state while presenting its own actions or position as that required by international law - that is, to align its own policy or actions as justified by, if not necessitated by, international law and to weaken the association of the other state with the ideal. This is naturally easier to do where the rules of international law are broadly in support of one's own policy preferences. Doing so well could at a minimum be expected to facilitate holding one's own against the most powerful, but this has been possible only so long as the most powerful have valued and sustained the ideology.

\section{THE IDEOLOGY IN PRACTICE}

The Cuban Missile Crisis represents the classic example of skilful use of the ideology of international law as a rhetorical fulcrum via which to achieve a peaceful outcome during a dispute. ${ }^{17}$ It will be recalled that the United States first detected deployment of medium range ballistic missiles to Cuba on 16 October 1962. After eight days of deliberation by the Executive Committee of the National Security Committee the United States imposed a quarantine on all Soviet cargo ships bound for Cuba. The Soviet ships turned back and the United States was then able to negotiate the removal of those missiles already installed in Cuba. This was one of the most tense and dangerous periods in the Cold War.

Skilful use of international law was an integral component of United States' crisis strategy, ${ }^{18}$ even if not conceptualised that way at the time and despite the fact that the Soviet Union was not actually doing anything illegal. Instead of alleging a Soviet breach of international law the United States emphasised the legality of its own position and implied the illegality of Soviet action, thereby upholding the image of a dichotomy of legal-illegal action. Rather than refer to a "blockade", which was illegal under customary international law, United States officials took the legal initiative and coined the term "quarantine", which they declared would be imposed around Cuba. The United States achieved a resolution under Article 6 of the Rio Treaty for collective action by the Organization of

16 Scott, above n 2, at 318 .

17 Scott and Withana, above n 13.

18 At 186. 
American States, ${ }^{19}$ which it argued was consistent with Article 53(1) of the UN Charter because it was recommendatory only. ${ }^{20}$ The United States was then in a position to demand that the Soviet Union remove the missiles knowing that if it did not do so the United States could even use military force while continuing to uphold the ideology more strongly than the Soviet Union.

The Dominican Republic Crisis was one in which Latin American states opposed to United States intervention were able to uphold the ideology relatively more strongly than the United States and to use international law to limit the basis on which the United States was able to intervene in the Dominican Republic. They successfully prevented an enlargement of the basis on which the United States could project its military power in the region, thereby using the ideology to achieve their political objectives. ${ }^{21}$ This serves to demonstrate both the distinction between complying with international law and upholding the ideology, and the successful use of the ideology by less powerful states.

The ideal was particularly important to allies of the United States. Because the ideology was so integral to the United States' modus operandi, allies were able to use it as a basis on which to influence United States policy choices. In Australia's case, for example, understanding how international law operates has been particularly important given Australia's long-term security relationship with the United Kingdom followed by a transition to the United States in 1942. Policy differences between Australia and the United States and between Australia and the United Kingdom were often mediated via international legal discussion. To take but one example, when Australia sought to convince the United States not to permit Japan to resume Antarctic whaling during the post-World War Two Occupation, United States officials did not listen to arguments couched in terms of Australia's security but did re-evaluate their position once Australia asserted that to permit them to whale would be illegal. $^{22}$

This example underlines the significance of support by the dominant state. Although the ideology is a tool at the disposal of all states, were the dominant state no longer to maintain the ideology, other states would not be able to draw on it in order to "do business" with the most powerful.

19 Inter-American Treaty of Reciprocal Assistance (signed 2 September 1947, entered into force 12 March 1948).

20 Article 53(1) requires that no enforcement action be taken under regional arrangements or by regional agencies without the authorisation of the Security Council.

21 Radhika Withana Power, Politics, Law: International Law and State Behaviour During International Crises (Martinus Nijhoff, Leiden, 2008) at 224.

22 Shirley V Scott "Australian Diplomacy opposing Japanese Antarctic Whaling 1945-1951: The Role of Legal Argument" (1999) 53 AJIA 179. 


\section{WHAT WOULD BE THE SIGNIFICANCE FROM A LEGAL AND POLITICAL PERSPECTIVE OF THE IDEOLOGY NO LONGER BEING UPHELD?}

The ideology has been strengthened internally by a logically consistent body of principles, rules and concepts premised on the ideology being true; within international law, the ideology broadly equates with legal positivism. Treatises and judgments have collectively upheld and reinforced the ideology. Externally, the ideology has been reinforced by political rhetoric that assumes the component principles to be true, and by actions that, in conjunction with the rhetoric, lend support for the truth of the principles. ${ }^{23}$

Importantly, from the perspective of the theory of International Law as Ideology it is not behaviour contrary to the principles per se that weakens the ideology. As critical theorists and practising international lawyers are well aware, these principles are not true in an absolute sense and the legal significance of an action may often be couched in multiple ways. Sidestepping the ideology where it is relevant and could be used as a fulcrum misses an opportunity to reinforce the ideology, while what weakens the ideology is a combination of rhetoric and action that implicitly asks its audience to believe the principles to be true while the audience at the same time gets a demonstration that this is not the case.

We have already seen that if the ideology were no longer being used as a diplomatic fulcrum in world politics that would indicate a shifting relationship of power in the international community. What, though, would be the implications of the ideal no longer being continually upheld and reinforced? Most fundamentally, perhaps, the United States would no longer be able to draw on the ideal as a basis on which to influence the policy choices of other states and it would potentially be difficult to reconcile different political positions on the basis of the ideal because it would not matter so much even if actions or policies were found to be inconsistent with international law. This could be expected to lead to a more unsettled international order, certainly until such time as it is replaced as the central ideology, or else modified. There could also be expected to be flow-on effects for other ideals that have gained strength through being associated with the ideal of international law. These include collective security, human rights, free trade and environmentalism. The broader character of the international system, its values and norms, would therefore also change.

\section{THE TURNING POINT? 2003 USE OF FORCE AGAINST IRAQ}

Although it would be difficult to "prove" in a conclusive manner, it would now seem that the 2003 invasion of Iraq may have marked a turning point in the strength of the ideology. United States actions so clearly undermined the image of international law conveyed by the rhetoric that it would be very difficult for the ideal to recover. Perhaps most blatantly highlighted was the political use of international law as opposed to the principle of neutrality; international law as an avenue to world

23 Scott, above n 2. 
peace was also revealed as blatantly untrue and the falseness of the image that international law dictates policy was displayed in neon signs. ${ }^{24}$

In the lead up to the United States' use of force against Iraq, United States foreign policy choices were legitimated by its portrayal of its position as justified by, if not dictated by, international law. The United States made a strong case for Iraq's non-compliance with Resolution 1441, thereby assuming the possibility of a clear compliance and non-compliance distinction in state behaviour and associating Iraq with the latter. ${ }^{25}$

In contrast, after the invasion, the failure to find weapons of mass destruction highlighted to observers that, rather than international law having constituted the driving force behind United States policy, international law rhetoric had been used to garner political support for a political policy of choosing to invade Iraq. The starkly political use of international law, contrary to the image of international law as dictating policy choices, detracted markedly from perceptions of the legitimacy of United States policy. ${ }^{26}$

The legitimacy of United States foreign policy declined further with revelations of prisoner abuse. As a policy choice, the invasion of Iraq was catastrophic for Iraqi society, with over half a million people estimated to have died as a result. ${ }^{27}$ The legacy has included the creation of ISIS and ongoing instability in the Middle East. Despite Obama's stronger support for international law, the 2003 invasion of Iraq by the United States and its allies continues to be cited by Putin, China and others as showing United States hypocrisy. ${ }^{28}$ In the years since we have seen both the side-lining of international law from the real action on the issues of the greatest importance to global security, ${ }^{29}$ and the weakening of the ideal of international law as a path to world peace. It is instructive to consider the role of international law in 2017 exchanges pertaining to the acquisition of nuclear weapons by North Korea in comparison to that we have already reviewed.

24 This section draws on Shirley V Scott and Olivia Ambler "Does Legality Really Matter? Accounting for the Decline in US Foreign Policy Legitimacy Following the 2003 Invasion of Iraq" (2007) 13 EJIR 67.

25 At 77.

26 Scott and Ambler, above n 24.

27 Neta C Crawford "Civilian Death and Injury in the Iraq War, 2003-2013" (Costs of War series, Watson Institute of International and Public Affairs, Brown University, March 2013) 1 at 16.

28 Vladimir V Putin "A Plea for Caution from Russia" The New York Times (online ed, New York, 11 September 2013); and Yong Deng "The Unwelcome Return: China Reacts to the US Strategic Pivot to Asia" in Peter CY Chow (ed) The US Strategic Pivot to Asia Cross-Strait Relations: Economic and Security Dynamics (Palgrave Macmillan, New York, 2014) 79 at 88.

29 Nico Krisch "The Decay of Consent: International Law in an Age of Public Goods" (2014) 108 AJIL 1. 


\section{THE 2017-2018 NORTH KOREAN NUCLEAR CRISIS}

North Korea was arguably pursuing its interests in line with its commitments under international law when, in 1993 the Democratic People's Republic of Korea announced that it would exercise its legal right of withdrawing from the Treaty on the Non-Proliferation of Nuclear Weapons (NPT). ${ }^{30}$ This would have meant that North Korea was no longer under a legal obligation not to develop nuclear weapons. The 1994 Agreed Framework, designed to keep North Korea within the regime, failed in either halting its nuclear ambitions or changing the decision to withdraw. ${ }^{31}$ North Korea announced its withdrawal in 2003; given that its International Atomic Energy Agency (IAEA) agreement was linked to its membership, this also came to an end. The United Nations Security Council in a series of resolutions imposed sanctions and by Resolutions 1718 and 1874 demanded that North Korea retract its announcement of withdrawal from the NPT and return "at an early date" to membership in the NPT and to a safeguards agreement with the IAEA.

North Korea conducted a series of tests in 2016 and 2017. Following and interspersed by these tests, North Korean supreme leader Kim Jong-un and United States President Trump engaged in a bellicose public exchange. What was particularly notable in contrast to the two nuclear-related crises discussed above was the paucity of reference to international law in these public exchanges. It is not that international law was irrelevant to developments. When Kim Jong-un threatened to send nuclear missiles to United States' territory, the United States might have been expected to seek international support by emphasising the illegality of threatening to use force as per Article 2(4) of the UN Charter. Instead, and in contrast to the case studies referenced above, Trump threatened ultimate destruction without any rhetorical reference to self-defence or international law, attracting widespread condemnation internationally. Kim Jong-un himself commented that President Trump's speech to the UN lacked "persuasive power that can be viewed to be helpful to defusing tension". ${ }^{32}$

Interestingly, North Korea did make rhetorical reference to self-defence and counter-measures: ${ }^{33}$

The UN Charter stipulates individual member states' rights to self-defence. Since the United States declared war on our country, we will have every right to make countermeasures, including the right to shoot down the United States' strategic bombers even when they're not yet inside the airspace border of our country.

30 Treaty on the Non-Proliferation of Nuclear Weapons 729 UNTS 161 (opened for signature 1 July 1968, entered into force 5 March 1970).

31 Agreed Framework between the United States of America and the Democratic People's Republic of Korea (21 October 1994).

32 Kim Jong-un, Supreme Leader of North Korea "Statement of Chairman of State Affairs Commission of the DPRK" (Pyongyang, 22 September 2017).

33 "North Korea calls Trump tweet 'a declaration of war'" CBS News (online ed, New York, 25 September 2017). 
Even if President Trump were to have tried drawing rhetorically on the ideology, there was likely little incentive for Kim Jong-un to compete to uphold the ideology. An ideology lends cohesion to a community or society and is a basis on which members can jostle and compete. But the ideology does not help those who are outside that community. North Korea has since George W Bush been treated as outside the international order - President Bush labelled it part of an "axis of evil" and President Trump has referred to it as a "rogue nation". ${ }^{34}$ This would seem to exclude North Korea from the community bound together through acceptance of the ideology of international law.

Interestingly, this case study also shows how the manner in which the United States for a number of years sought to address the crisis - via the Security Council - may well have had the effect of weakening the internal cohesion of international law, with implications for the strength in which the ideology is upheld during legal argument. The demand that North Korea re-accede to a treaty from which it had withdrawn according to the treaty's terms would, according to Daniel Joyner: ${ }^{35}$

... seem to carry serious implications with regard to the consensual nature of all of the sources of international law, which is in turn intimately linked to the sovereign character of states in the international system.

International law did not feature per se in the 2018 Trump-Kim summit statement, a glaring missed opportunity to sustain the principle that international law is capable of resolving disputes in world politics. ${ }^{36}$

\section{FROM INTERNATIONAL LAW TO RULES-BASED INTERNATIONAL ORDER}

One recent shift away from rhetorical references to the ideal of international law on the part of the United States and allies has been the increasing preference for the term "rules-based international order" or simply "rules-based order". The 2000 United States National Security Strategy referred five times to international law, and once to a rules-based international order; the 2015 version included only three references to international law and five to a rules-based order or system (RBO). ${ }^{37}$ An RBO was closely linked to United States' leadership. ${ }^{38}$

34 Donald J Trump (@realDonaldTrump) "North Korea is a rogue nation which has become a great threat and embarrassment to China" <https://twitter.com/realdonaldtrump/status/904307898213433344?lang=en>.

35 Daniel H Joyner "The Security Council as a Legal Hegemon" (2012) 43 GJIL 225 at 251.

36 "The Trump-Kim Summit Statement: Read the Full Text" The New York Times (online ed, New York, 12 June 2018).

37 United States Government National Security Strategy (February 2015) at 3.

38 At 21 
Any successful strategy to ensure the safety of the American people and advance our national security interests must begin with an undeniable truth - America must lead. Strong and sustained American leadership is essential to a rules-based international order that promotes global security and prosperity as well as the dignity and human rights of all peoples. The question is never whether America should lead, but how we lead.

The 2015 National Security Strategy asserted that the rules-based international order was under threat: $^{39}$

Our economy is the largest, most open, and innovative in the world. Our leadership has also helped usher in a new era of unparalleled global prosperity. Sustaining our leadership depends on shaping an emerging global economic order that continues to reflect our interests and values. Despite its success, our rulesbased system is now competing against alternative, less-open models.

Interestingly the 2017 United States National Security Strategy did not mention RBO at all - but it also made only three references to "international law".40

United States allies have both mimicked and exaggerated the rhetorical shift from international law to RBO. The United Kingdom's 2015 National Security Strategy and Strategic Defence and Security Review included three references to international law and 30 to a rules-based international order or system, while the 2016 Australian Defence White Paper included as many as 56 references to a rules-based international order or system. ${ }^{41}$ The speeches of Julie Bishop, Australia's then Foreign Minister, were replete with such references, such as this example from a speech on the occasion of the fiftieth anniversary of Association of Southeast Asian Nations (ASEAN): ${ }^{42}$

Australia and ASEAN are both clear beneficiaries of the international rules-based order that has underpinned our growth and prosperity. ... There is a compelling need to defend the rules-based order in the region. ... Much depends on the ability of likeminded nations working with ASEAN in supporting and defending the international rules-based order.

The 2017 Australian Foreign Policy White Paper also made fifteen references to a "rules-based" order or international order.

39 At 15.

40 United States Government National Security Strategy (December 2017).

41 Nick Bisley and Benjamin Schreer "Australia and rules-based order in Asia: Of principles and pragmatism" (2018) 58 Asian Survey 302 at 302. See also Department of Defence 2016 Australian Defence White Paper (2016).

42 Julie Bishop, Australian Minister for Foreign Affairs "50th anniversary of ASEAN" (speech at event celebrating 50th anniversary of ASEAN, Bangkok, 3 August 2017). 
The New Zealand Government 2016 Defence White Paper made 18 references to an RBO or rules-based system. ${ }^{43}$ New Zealand Prime Minister Jacinda Ardern stated in her first foreign policy speech in office that: ${ }^{44}$

At a time when risks to global peace and security are growing and the rules-based system is under such

pressure, we must recommit ourselves to the cause of non-proliferation and disarmament, and to the norms

and rules which support those endeavours.

\section{HOW CAN WE ACCOUNT FOR THE RHETORICAL SHIFT?}

Particularly given the centrality of the ideal of international law to United States power and influence, perhaps the most obvious question to be asked about this shift in rhetoric is why it has been chosen. The United States examples above captured the idea that the RBO was associated with United States leadership and was something to be protected, and that it had underpinned security as well as prosperity; but why not simply refer to international law itself? This could be answered on various levels. Let us begin by considering some of the more obvious explanations.

Perhaps most basically, those using the new rhetoric may well assume RBO to be synonymous with international law. From the perspective of this article, on the other hand, use of RBO language by the United States seems to indicate a lack of appreciation of the role international law played in the rise of the United States and its success. The nature of United States' engagement with international law, of which strategic use of the ideology of international law was integral, can be understood heuristically as a quest for legal security. ${ }^{45}$ The essence of legal security as practiced by the United States was the protection of its domestic political and legal system from external influence via law. The United States was at the same time striving to influence the legal and policy choices of other states via international law. The net result of blocking the influence of international law on its own legal system and impacting on the legal systems of others was an increase in relative United States' influence over other states. Hence from an historical perspective it can be said that the United States quest for legal security was integral to the rise of the United States. ${ }^{46}$

In contrast to an understanding such as this, there is a long history in the United States academy of realism downplaying the value of international law. Of particular note is that since the publication in 2005 of Eric Posner's The Limits of International Law, a small group of international lawyers in the United States, including also Goldsmith, Yoo and Vermeule, the so-called "New Realists", have propagated their belief that international law has little impact on a state - that where a state might

43 Ministry of Defence 2016 Defence White Paper (June 2016).

44 Jacinda Ardern, Prime Minister of New Zealand "Speech to New Zealand Institute of International Affairs" (Wellington, 27 February 2018).

45 Scott, above n 3.

46 Scott above n 3. 
appear to be behaving as required of it by international law, that is little more than coincidence. Rather than this be a matter of academic debate in the halls of ivory tower universities, the New Realists turned their "intellectual vision into a strategy reality", directly impacting policy in Washington. ${ }^{47}$

The shift in rhetoric from international law to RBO may also reflect the consequences for international law of a shifting distribution of power. This has made it difficult to achieve new multilateral treaties and to progress stalled treaty regimes. Precisely because international law is as democratic as it is, represented most fundamentally in the principle of the sovereign equality of states, it has become increasingly difficult for the United States and allies to lead the creation of treaty regimes that reflect policy choices - or perhaps to be more precise, it has become far easier for rising and middle powers - in many cases influenced by non-governmental organisations promoting specific agendas, to establish treaty regimes with which the United States disagrees. China did well out of the core treaty regimes of the post-World War Two international order, ${ }^{48}$ and has also drawn strategically on the ideal. ${ }^{49}$ Weakening and/or supplanting that ideal reduces the scope for China to draw on the ideal to its own strategic advantage vis-à-vis the United States.

The key global treaties of the post-World War Two decades involved compromise, and the terms of those compromises were generally unequal. ${ }^{50}$ With the shifting global distribution of power, the states rising in influence are simply not prepared to accept unfair treaties, so a number of the treaty regimes are blocked; for example, the World Trade Organization has been blocked, with the latest round of negotiations having been stalled and the action largely moving to bilateral and plurilateral agreements. The United States has of course long had difficulty ratifying treaties because of the requirement that a treaty have the support of two-thirds of the Senate. The United States Department of State developed a number of work-arounds to counter this impediment, ${ }^{51}$ but over time others became tired of negotiating compromises in treaties with the United States, which the United States never seemed to follow through to ratification.

While in strict legal terms the United States has done nothing wrong by choosing not to become party to a treaty establishing an international criminal court whose design is not in line with United States-preferred design choices, or to stay outside a Nuclear Weapons Convention that would require

47 Jens David Ohlin The Assault on International Law (Oxford University Press, Oxford, 2015) at 14.

48 See Shirley V Scott "Peace by International Law" in Elin Bjarnegard and Joakim Kreutz (eds) Debating the East Asian Peace: What it is. How it came about. Will it last? (NIAS Press, Copenhagen, 2017).

49 Scott, above n 3, at 229-230.

50 See Shirley V Scott "The Problem of Unequal Treaties in Contemporary International Law: How the Powerful Have Reneged on the Political Compacts within which Five Cornerstone Treaties of Global Governance are Situated" (2008) 4 JILIR 101.

51 David Kaye "Stealth Multilateralism: US Foreign Policy without Treaties-or the Senate" (2013) 92 Foreign Affairs 113. 
actions that United States policy-makers do not deem in the national interest, the United States has met with considerable criticism for just such choices. The very success of the international law project as an alternative to the 19th century Europe style alliance system, together with the pervasiveness of a positive image of international law shored up by the rhetorical alignment of international law with human rights and peace, has been mobilised by single issue international actors to garner support for their own agendas; non-governmental organisations' and United States' critics do not typically give public recognition to what might be considered legitimate nuances of treaty ratification choices in their public diplomacy and acts of normative contestation. It may thus be that this shift in rhetoric is the best that the United States and allies can do as its relative power and influence declines.

\section{THE POTENTIAL IMPLICATIONS OF THE SHIFTING RHETORIC}

Although RBO rhetoric on the part of the United States government and allies may in part reflect the shifting distribution of power, the insight of an ILI analytical approach is that it may at the same time unwittingly add to that shift. ILI has as a core precept that precise language matters and, as we have seen, one of the primary ways that the precise nature of the ideology underpinning the international order matters is because it serves as a rhetorical fulcrum in diplomacy.

United States policy-makers may refer to a RBO in relation to the South China Sea so as not to highlight the apparent hypocrisy between calling on China to align its behaviour with the United Nations Convention on the Law of the $\mathrm{Sea}^{52}$ while itself remaining outside the regime, but because the term RBO is closely associated with the United States, China can simply counter by asking "whose rules?"53 International law has as an underlying principle that international law is universal in the sense of being politically neutral, but if RBO were to replace international law as an ideology underpinning the conduct of diplomatic bargaining, it would likely weaken this principle with no obvious political comeback.

The ultimate danger of the shift in rhetoric is, however, the scope it gives for competitors of the United States to use the broader term in their diplomatic manoeuvring against the United States. Taken at face value, the most obvious difference between an international law-based order and an RBO is that "RBO" is a broader term: the rules need not even be legal rules. Western proponents of the term are likely attempting to capture soft law, institutional arrangements, and norms beyond those that have reached the status of custom and that may not appear in treaty law. Although it is unlikely to be the intention of Western policy-makers using the term, another state using the ideology to seek to constrain United States policy choices could, particularly as other states have increasing influence

52 United Nations Convention on the Law of the Sea 1833 UNTS 3 (opened for signature 10 December 1982, entered into force 16 November 1994).

53 Cheng Jingye "Arbitration on South China Sea Dispute Fatally Flawed" The Australian (online ed, Sydney, 14 July 2016). 
over the design of new institutions and norms, potentially use the term against the United States. An RBO might even be based on Sharia law, for example, but the United States would be unlikely to welcome this form of RBO. An RBO might simply consist of a set of rules that a newly dominant state makes up, perhaps based on its domestic law, and imposes on those in a tributary relationship with it.

International law is a system in which the United States has been dominant but not completely so. Yes, the United States has been the reference point for debates on international law and had a disproportionate influence over its post-World War Two expansion, but the United States has not simply been able to make up the rules to suit itself. As a system with its own internal dynamics, international law serves to moderate the impact of power on those rules and their implementation and provides means for nuance in states exercising their sovereign right to participate: in treaty law, for example, a state may usually enter a reservation or might not sign but later accede; during the course of the regime life parties may effectively agree to re-interpret a component principle as has been the case with the United States and China in relation to the principle of common but differentiated responsibilities and respective capabilities. ${ }^{54}$ Ironically, even the United Nations Convention on the Law of the Sea was the product of a mammoth diplomatic undertaking, in which China had a voice; ${ }^{55}$ China in fact expressed satisfaction at the package deal outcome whereas the United States failed to sign the final text.

\section{CONCLUSIONS}

The period from the end of World War One until recently can be understood to have represented the United States era in international law. In recent years, however, the ideology would seem to have often been side-lined and to be weakening. It was side-lined, for example, in the Iran "Deal" and has not featured strongly in the United States' approach to the North Korea crisis. The United States has been in a bit of a "catch 22": as the distribution of power has shifted, it has been more difficult to draw on the ideology of international law to achieve United States political objectives. It needs to be remembered, though, that the United States did draw successfully on the ideology during the Cuban Missile Crisis, despite the Soviet Union not having acted unlawfully. By treating North Korea as an outsider to the international order and minimising its referencing of international law in its recent dispute with North Korea, the United States has actively increased the rate by which the ideology is being side-lined.

Viewed from today's perspective, it seems that the 2003 invasion of Iraq may well have represented a turning point, with the ideology not appearing to have recovered from being so strikingly

54 Mary J Bortscheller "Equitable but Ineffective: How the Principle of Common but Differentiated Responsibilities Hobbles the Global Fight against Climate Change" (2010) 10 Sustainable Development Law \& Policy 49.

55 Sébastien Colin "China, the US, and the Law of the Sea" (2016) 2 China Perspectives 57 at 58-59. 
undermined by United States' rhetoric and actions. Current rhetoric around an RBO may actively weaken the ideology, and yet while this choice of rhetoric may at first glance appear puzzling, it may be the best that can be done at this stage. If the ideology were to remain strong, it would be easier for China to make strategic use of the ideal as it approaches power parity with the United States and for a variety of international actors to replace norms, such as nuclear non-proliferation, that had been integral to the United States-led international order. But weakening the ideology makes it far less likely that international law can act as a fulcrum on which to mediate differing positions in relation, for example, to the South China Sea. It is still difficult to think of a basis on which to address this and other issues of international security that would be preferable to that of respect for the ideal of international law. 
